\title{
The fragility of competition and cooperation between Indonesia, China and the EU from an SME and cooperative point of view
}

\author{
N.I. Soesilo \\ Department of Economics, Faculty of Economics and Business, Universitas Indonesia, Depok, Indonesia
}

\begin{abstract}
The increased maritime cooperation under the revival of the Silk Road theme has been initiated since President Jokowi's leadership of Indonesia. Many controversial efforts have been implemented since then to materialise this cooperation with China. Yet Indonesian Small Medium Enterprises (SMEs) and cooperatives have been worried by the influx of Chinese products due to their low price. This is not cooperation but the opposite, they compete with one another. However, both Indonesia and Chinese SMEs and cooperatives are donor recipients of European Union (EU) funding, some of which are disbursed through IFIs (International Financial Institutions) in cooperation with both governments. As stated in the Fragile States Index these recipient countries are considered by donor countries to be fragile States. The Triangular Cooperation $(\mathrm{TrC})$ of Indonesia, China and the EU has existed as additional to the South-South cooperation between Indonesia and China. This paper will evaluate the relevance of the EU's point of view as the donor country using their ten principles to cope with Fragile States, especially in assisting the TheySMEs and cooperatives in both Indonesia and China. Despite the upper position of the EU as the donor country in the lending scheme to China and Indonesia, this higher position of EU has been labelled only 'normative power' not the real power, especially when dealing with China as the world's new superpower.
\end{abstract}

\section{INTRODUCTION}

China and Indonesia were categorised as fragile States with the same rank in 2016 by the Fragile State Index sponsored by the European Union (EU) within the Triangular Cooperation ( $\mathrm{TrC}$ ). Aid to fragile States represents 30\% of all ODA (Official Development Assistance) missions along with 116,000 UN peacekeeping personnel (Blue Helmets) in 2010 which was eight times more than in 1999. Both Indonesia and China encouraged inclusive growth through the development of Small Medium Enterprises (SMEs) as well as cooperatives, despite their objective in a rigorous national economic development that prioritized growth that often create trade-off with equality. Fragile States are considered as very important from the point of view of donor countries such as the EU, because Fragile States are mostly off track for most Millenium Development Goals (Ramalingam, 2012), although many agendas of development, security, diplomacy, trade, migration, and beyond are actively deployed by international actors. However, EU influence has been labelled as normative power (Manners, 2000) rather than the doer. Since 2005, the Fragile State Index (FSI) has been calculated annually in many countries worldwide, supporting the EU international assistantship programme, and is available to be used for international economic, political and social research. However, beyond traditional conceptions of the EU's international role (Hedley Bull in Manners, 2002), this role dismisses the suggestion that the European Community (EC) represents a 'civilian power' in international relations, maintaining that in fact it is only a normative power. Kaplan states that EU as donor countries have often been confused by the definition and categorization of Fragile States, with some even calling them a 'wicked problem' because of its obscured causality. Both Indonesia and China are praised 
by Kaplan because of the social glue that lubricates business and has encouraged leaders to focus on inclusive development, even though sometimes they are not compatible with the rule of thumb of good governance, or progressive taxes effort, as often encouraged by common Western policy playbook.

Die Seidenstrasse (the Silk Road) was named by the German geologist, Baron Ferdinand von Richthofen, as the trade and communication network, enriched by the intellectual (science and technologies) and cultural (language, art, literature and craft) exchange and religion (Silk Road Foundation, 2007) that reflects cooperation, which is embedded in fragile state support. However, this does not mean that as fragile states, both China and Indonesia as EU's assisted countries do not have their own cooperation or competition. The SSC and $\mathrm{TrC}$ partnerships are vital forovercoming the current development challenges and reaching internationally agreed development goals, including the Millennium Development Goals as elaborated by the UNDP.

The increased maritime cooperation between Indonesia and China under the revival of the Silk Road theme has been implemented since President Jokowi's leadership of Indonesia. Many controversial efforts have been conducted since then to materialise this cooperation with China. Yet the Indonesian SMEs and cooperatives have been worrying about the influx of Chinese products because of their low price, and have therefore been competing with one another. However, both Indonesian and Chinese SMEs and cooperatives are donor recipients of EU funding, eventhough some of the funding are disbursed indirectly because the International Financial Institutions give the money to the governments first before goes to them. It is because both countries are considered as Fragile States due to their high fragility magnitude as stated by Fail States or Fragile State Index.

Cooperation is the opposite of competition. IPorter's national diamond 'Competitive Advantage of Nations (1990)' he proclaims a bridge between the theoretical literatures in strategic management and international economics and provides the basis for improved national policies on competitiveness (Porter in Davies \& Ellis, 2000). The 'competitive advantage' of a nation's industries is determined by the configuration of four broad attributes of the national location, referred to as the 'home base'. These are the now-familiar corners of the 'national diamond', namely, (1) factor conditions, (2) demand conditions, related and supporting industries, and firm strategy, structure, and rivalry (Davies \& Ellis, 2000). On the other hand, a distinguished commercial and social entrepreneurship cooperation is established (Austin et al. 2006), as both built alliances are created by mutuality of interests, similar to incongruity that ends up with an unexpected strategic fit. There is no difference between business and non-profit partnerships, and those between business and business. However, commercial entrepreneurship is different from social entrepreneurship in the identification, evaluation and exploitation of opportunities leading to profits because of social value. Fragility is the opposite of competitiveness, as it represents a weakness as well as a critical aspect that should be prevented immediately to mitigate further risk.

\subsection{Review of literature}

Unlike Porter's work of improved national policies based on competitiveness, the fragility being used in this research is based on Fund for Peace's Fail State Index (FSI) or Fragile State Index, which has been creating some calculation about country fragility since 2005 focusing on the indicators of risks using the CAST Software in its computation and based on thousands of articles and reports that are processed from electronically available sources. This index is produced annually and usage is encouraged to develop ideas for promoting greater stability worldwide. Using the FSI data for calculating total annual fragility growth from 2005 to 2016, it was found that fragility in Indonesia has decreased by 1.4 per cent, while in China it has increased by 0.7 per cent, and in the EU decreased 0.1 per cent (using annual growth of 2006-2016). In this case, Indonesia shows a better picture compared to the other two countries, as seen in Tables 1,2 and 3.

According to the UN, the Triangular Cooperation $(\mathrm{TrC})$ is a common Southern-driven partnership between two or more developing countries, supported by a developed country(ies) 
Table 1. The growth of fragility in China and Indonesia based on the FSI data.

\begin{tabular}{|c|c|c|c|c|c|c|c|c|}
\hline \multirow{2}{*}{$\begin{array}{l}\text { Year } \\
\text { Country }\end{array}$} & \multicolumn{2}{|l|}{2005} & \multicolumn{2}{|l|}{2016} & \multicolumn{2}{|l|}{2017} & \multicolumn{2}{|c|}{ Fragility growth } \\
\hline & IDN & China & IDN & China & IDN & China & IDN & China \\
\hline Fragility Rank & 47 & 75 & 86 & 86 & \multicolumn{2}{|c|}{ Projection } & & \\
\hline Total Fragility & 87 & 72.3 & 74.9 & 74.9 & 73.5 & 78.1 & $-1.4 \%$ & $0.7 \%$ \\
\hline Demographic Pressures & 8.6 & 6.8 & 6.8 & 6.9 & 7 & 7.5 & $-1.7 \%$ & $0.9 \%$ \\
\hline Refugees and IDPs & 7 & 5 & 5.6 & 5.1 & 5.4 & 6.0 & $-2.1 \%$ & $1.7 \%$ \\
\hline Group Grievance & 6.3 & 7.4 & 7.3 & 8.1 & 7.6 & 8.4 & $1.9 \%$ & $1.1 \%$ \\
\hline Human Flight & 8.9 & 6 & 6.6 & 4.6 & 5.7 & 4.4 & $-3.3 \%$ & $-2.3 \%$ \\
\hline Uneven Development & 9 & 9 & 6 & 7.5 & 5.9 & 7.4 & $-3.1 \%$ & $-1.5 \%$ \\
\hline Poverty and Economic Decline & 4 & 0.5 & 5.5 & 4.1 & 5.7 & 4.3 & $3.8 \%$ & $63.9 \%$ \\
\hline Legitimacy of the State & 9.2 & 8.6 & 5.3 & 8.3 & 5.4 & 7.9 & $-3.7 \%$ & $-0.7 \%$ \\
\hline Public Services & 4 & 2.9 & 6.1 & 5.9 & 6.3 & 6.8 & $5.2 \%$ & $11.2 \%$ \\
\hline Human Rights & 8.6 & 8.9 & 7.4 & 8.7 & 6.3 & 9.0 & $-2.4 \%$ & $0.1 \%$ \\
\hline Security Apparatus & 7.6 & 7 & 5.9 & 5.6 & 6.1 & 5.9 & $-1.8 \%$ & $-1.3 \%$ \\
\hline Factionalised Elites & 8.8 & 8.4 & 7 & 7.2 & 6.6 & 6.8 & $-2.3 \%$ & $-1.6 \%$ \\
\hline External Intervention & 5 & 1.8 & 5.4 & 2.9 & 5.5 & 3.7 & $1.0 \%$ & $8.7 \%$ \\
\hline
\end{tabular}

IDP $=$ Internally Displaced Person .

Table 2. International migrant stock is the number of people born in a country other than that in which they live. It also includes refugees.

\begin{tabular}{lllllll}
\hline Country code & 1965 & 1975 & 1985 & 1995 & 2005 & 2015 \\
\hline CHN & 260479 & 298474 & 323937 & 442198 & 678947 & 978046 \\
IDN & 1475121 & 928340 & 593098 & 378960 & 289568 & 328846 \\
CHN/IDN & 0.176581 & 0.321514 & 0.546178 & 1.166872 & 2.344689 & 2.974176 \\
\hline
\end{tabular}

or multilateral organisation(s), to implement development cooperation programmes and projects. In this case, the $\operatorname{TrC}$ comprises Indonesia, China and the EU. Funding from EU has been dominating IFIs. One of them is the UN IFAD (International Fund for Agricultural Development). On 31 December 2012, EU dominated 31\% from the majority share of non-member countries, whose number reached $50.2 \%$ in the UN IFAD, while the World Bank were only $7.85 \%$ ). It is based on consolidated financial statements audited by Deloitte (Soesilo, 2014). The number were calculated accumulatively from 1978-2012, including Supplementary Contribution and project co-financing to UN IFAD (IFAD, 2013) as well as the contribution of Belgium BFFSJP (Belgian Fund for Food Security Joint Programme) that had the biggest share of $16.75 \%$, followed by the Netherlands $(7.9 \%)$ and the UK $(2.95 \%)$, while Indonesia was only $0.004 \%$. In 2014, from member state shares, China's share was $1.3 \%$ and Indonesia was $0.8 \%$. For the purpose of providing aid, the EU utilized the Fragile State Index (FSI) report as a modification of Fail State Indeks report, even though it was not publicly announced.

At the initial formation, the accumulation score of countries shown by the FSI annual index was categorised into the following: 'alert', 'warning', 'moderate' and 'sustainable'. Both the Fail State Index or the Fragile State Index use the categorisations of: 'very high alert', 'high alert', 'alert', 'warning', 'high warning', 'elevated warning', 'stable', 'more stable', 'very stable', 'sustainable', and 'very sustainable'. By looking at the trend of time series scores, the growth of FSI components can be used to calculate the most critical aspect that should be prevented immediately. It is a tool for highlighting the most critical warning pressures that a country experiences. Among the social, economic and political aspects, which is the most fragile can be easily found and then underlined to avoid entering the brink of failure. 
Table 3. EU countries and their fragilities based on FSI's data from 2006-2016 and its projections.

\begin{tabular}{|c|c|c|c|c|c|c|c|c|c|c|c|c|c|}
\hline EU countries & Growth & 2017 & 2016 & 2015 & 2014 & 2013 & 2012 & 2011 & 2010 & 2009 & 2008 & 2007 & 2006 \\
\hline ustria & $0.6 \%$ & 27.7 & 27.5 & 26.0 & 28.5 & 26.9 & 27.5 & 27.3 & 27.2 & 27.6 & 25.9 & 26.0 & 26.1 \\
\hline Belgium & $3.1 \%$ & 32.3 & 29 & 30.4 & 32.0 & 30.9 & 33.5 & 34.1 & 32.0 & 33.5 & 29.0 & 25.5 & 24.0 \\
\hline Bulgaria & $-0.7 \%$ & 57.5 & 53.7 & 55.4 & 54.4 & 55.0 & 56.3 & 59.0 & 61.2 & 61.5 & 58.5 & 60.3 & 62.1 \\
\hline Croatia & $-0.8 \%$ & 56.3 & 52.4 & 51.0 & 52.9 & 54.1 & 56.3 & 57.3 & 59.0 & 60.1 & 59.4 & 60.5 & 61.9 \\
\hline Cyprus & $-0.4 \%$ & 67.7 & 64 & 66.2 & 67.9 & 67.0 & 66.8 & 67.6 & 68.0 & 68.9 & 69.7 & 70.2 & 70.5 \\
\hline Czechia & $-0.2 \%$ & 40.7 & 40.8 & 37.4 & 39.4 & 39.9 & 39.5 & 42.4 & 41.5 & 42.6 & 42.1 & 42.1 & 41.8 \\
\hline Denmark & $0.8 \%$ & 22.6 & 21.5 & 21.5 & 22.8 & 21.9 & 23.0 & 23.8 & 22.9 & 23.2 & 21.5 & 22.2 & 24.8 \\
\hline Estonia & $.5 \%$ & 48.0 & 43.4 & 43.8 & 45.2 & 45.3 & 47.5 & 49.3 & 50.7 & 51.2 & 51.0 & 50.5 & 51.0 \\
\hline Finlar & $0.3 \%$ & & 18.8 & 17.8 & 18.7 & 18.0 & 20.0 & 19.7 & 19.3 & 9.2 & 8.4 & .5 & 18.2 \\
\hline France & $0 \%$ & 34.2 & 34.5 & 33.7 & 34.8 & 32.6 & 33.6 & 34.0 & 34.9 & 35.3 & 34.8 & 34.1 & 34.3 \\
\hline Germany & $-1.4 \%$ & 33.6 & 28.6 & 28.1 & 30.6 & 29.7 & 31.7 & 33.9 & 35.4 & 36.2 & 37.3 & 38.4 & 39.7 \\
\hline Greece & $1.6 \%$ & & 55.9 & 52.6 & & & 50.4 & 47.4 & 45.9 & 46.1 & 45.4 & 43.5 & 41.1 \\
\hline & & & 52.7 & 49.1 & & & 48 & 48.7 & 50.1 & 50.7 & 50.9 & 51.2 & 46.7 \\
\hline & & & 22.5 & 24.7 & & & & 5.3 & & .6 & 19.9 & .5 & 18.6 \\
\hline tal & & 2.5 & 43.1 & 43.2 & 43.4 & 44.6 & 45.8 & 45.8 & 45.7 & 43.9 & 39.9 & 37.1 & 35.1 \\
\hline Latv & $.6 \%$ & 52.3 & 47.4 & 48.6 & 48.0 & 47.9 & 51.9 & 54.2 & 55.4 & 54.6 & 54.5 & 56.7 & 56.2 \\
\hline Lithe & $.7 \%$ & 45.8 & 42.4 & 43.0 & 43.2 & 43.0 & 44.2 & 45.3 & 47.8 & 48.0 & 48.7 & 49.0 & 49.7 \\
\hline Luxen & $-0.8 \%$ & 25.9 & 24.1 & 22.2 & 24.6 & 23.3 & 25.5 & 26.1 & 27.3 & 27.6 & 27.9 & 28.1 & \\
\hline Malta & $-0.7 \%$ & 45.3 & 39.6 & 40.9 & 43.0 & 42.4 & 43.8 & 45.4 & 48.2 & 48.8 & 48.3 & 48.5 & \\
\hline Nethe & $-0.1 \%$ & 27.8 & 28.2 & 26.8 & 28.6 & 26.9 & 28.1 & 28.3 & 27.9 & 27.0 & 27.3 & 28.6 & 28.1 \\
\hline ola & $-0.5 \%$ & 45.1 & 40.7 & 39.8 & 42.1 & 40.9 & 44.3 & 46.8 & 49.0 & 49.6 & 47.6 & 47.6 & 47.9 \\
\hline & $-0.2 \%$ & 32.2 & 29.2 & 29.7 & 33.1 & 32.6 & 34.2 & 32.3 & 33.1 & 32.7 & 31.8 & 32.4 & 32.7 \\
\hline & $-0.6^{\circ}$ & 58.7 & 52.9 & 54.2 & 56.9 & 57.4 & 59.5 & 59.8 & 60.2 & 61.3 & 59.9 & 60.9 & 62.6 \\
\hline & - & 47.1 & 44.9 & 42.6 & 45.3 & 45.3 & 47.4 & 47.1 & 48.8 & 8.6 & 48.8 & 49.3 & 49.9 \\
\hline & -0 & & 33.9 & 31 & 32.6 & 32.3 & 34 & 35.5 & 36.0 & 36.3 & 37.1 & 37.5 & 36.8 \\
\hline & & & 39.8 & & & & & & 43.5 & 3 & 41.6 & 39.2 & 37.4 \\
\hline & & & & & & & & & 20.9 & 0.6 & 19.8 & 19.3 & 18.2 \\
\hline UK & $-0.1 \%$ & 33.8 & 32.4 & 33.4 & 34.3 & 33.2 & 35.3 & 34.1 & 33.9 & 33.6 & 32.9 & 34.1 & 34.2 \\
\hline Average & $-0.1 \%$ & 39.7 & 38.09 & 37.7 & 39.0 & 38.5 & 40.0 & 40.6 & 41.0 & 41.2 & 40.4 & 40.4 & 40.4 \\
\hline Max & & & 64 & 66.2 & 67.9 & 67.0 & 66.8 & 67.6 & 68.0 & 68.9 & 69.7 & 70.2 & 70.5 \\
\hline Min & & & 18.8 & 17.8 & 18.7 & 18.0 & 20.0 & 19.7 & 19.3 & 19.2 & 18.4 & 18.5 & 18.2 \\
\hline
\end{tabular}

By underlining pertinent issues in Fragile State Indexes over time, the risk assessment can be used as an early warning of conflict that is accessible to policymakers and the public at large.

Both Indonesia and China are categorised as elevated warning countries in 2016 and positioned at the same 86th rank. However, based on previous record, in 2005 Indonesia was ranked 47 th in the Failed State Index, while China was in the 75th. It means China has worsening trends compared to Indonesia. To see the more detail performance, from the similar worsening trends in Indonesia and China, they are grouped in the three following components with their increasing annual fragility growths in brackets: group grievance (Indonesia and China deteriorated by $1.90 \%$ and $1.1 \%$ consecutively), poverty and economic decline (Indonesia and China deteriorated by $3.80 \%$ and $63.9 \%$ sequentially), public services (deteriorating by $5.18 \%$ and $11.2 \%$ for Indonesia and China consecutively) and worsening fragility due to external intervention at a rate of 0.97 per cent for Indonesia, and 8.7 per cent for China. However, China has three additional failing trends, while Indonesia is better off due to the opposite inclination. Pairing them together with their annual growth in brackets, the findings are as follows: the Demographic Pressures fragility (China increased by $0.9 \%$, while Indonesia decreased by $1.7 \%$ ), fragility due to Refugees and Internally Displaced Persons (China increased by $1.7 \%$, while Indonesia decreased by $2.1 \%$ ), and Human Rights fragility (China increased by $0.1 \%$, while Indonesia decreased by $2.4 \%$ ). A similar annual decreasing fragility happened for both countries in increasing state legitimacy; Indonesia and China are both better off with 3.7 per cent and 1.7 per cent consecutively. In total, the number of 
decreasing risk indicators in Indonesia is eight, while in China it is five, which indicates that Indonesia has better trends compared to China as can be seen in Table 1.

Meanwhile, the EU is a politico-economic union of 28 member states that are located primarily in Europe with an estimated population of over 510 million, about two times of that of Indonesia and one third of China. Brexit is the referendum result which urged that the UK should leave the EU, based on more than 30 million people voting on Thursday 23 June 2016 (Wheeler and Hunt, 2016).

Historically, the Silk Road, die Seidenstrasse was named by the German geologist, Baron Ferdinand von Richthofen (UNESCO, 2000), as the trade and communication network enriched by intellectual (science and technologies) and cultural (language, art, literature and craft) exchange and religion. In recent developments, as Jokowi put it, Indonesia has rich natural resources and China has knowledge and experience in the field of infrastructure. President Xi Jinping from China promised to support Indonesia's plans to develop its maritime infrastructure (the diplomat.com, 2015).

The increased maritime cooperation under the revival of the Silk Road theme has been conducted since President Jokowi has been leading Indonesia. Many controversial efforts have been made since then to materialise this cooperation, such as the development of infrastructure in Indonesia by employing Chinese workers and inviting the same number of Indonesians to China. A lot of resentment spurred by social media that might ignite conflicts have been setoff. This paper will elaborate ten ways on how to cope with fragile States Principles especially regarding the involvement and participation of micro small enterprises and cooperatives.

In the eyes of the EU (Farnell and Crookes, 2016), China is often characterised as operating in ways that accord with a broadly realist world view of international relations, premised on competing power dynamics between sovereign states, building alliances and mitigating threat perceptions in a modern international system whose anarchy is only partially offset by the evolution of issue-based institutions and regulatory regimes. The EU, by contrast, is typically characterised by a distinctive post-Westphalian organisation whose members have willingly agreed to bring together sovereignty and accepted a hint of supranational authority over major areas of domestic and international policymaking.

The Fragile State Index, however, is calculated from the point of view of the EU (representing the West). No wonder that both Indonesia and China are considered as at 'elevated warning' levels in Fragile State Indexes. Both China and Indonesia are non-Western Countries and recipients of the funding. As a whole, according to the FSIs, the EU is considered as stable, despite the fact that Brexit has been agreed upon. From 28 member countries in EU, there are ten states that have shown an increase in their fragility in the period 2006-2016, that is, Austria, Belgium, Finland, France, Greece, Hungary, Ireland, Italy, Spain and Sweden, as seen in Table 3. However, the following states show more stability: Bulgaria, Croatia, Cyprus, Czechia, Denmark, Estonia, Germany, Latvia, Lithuania, Luxembourg, Malta, the Netherlands, Poland, Portugal, Slovakia, Slovenia, the United Kingdom. The average growth of fragility from 2006 to 2016 is minus $0.1 \%$.

Using Hellsten, Sirkku's dual analytical tool, first the polarisation of Western and nonWestern ways of thinking, and second, the gap analysis about the desired and existing outcome in a multicultural environment and/or global context, the similarity of conflicts between two different theoretical and ethical frameworks exists. In international human rights discourse, two theoretically incompatible views exist. Third World communitarians claim that a form of cultural imperialism smuggles the undesirable Western egoist lifestyle (like the EU) into non-Western traditional communalist cultures as an attempt by Western liberal individualists to universalise their value orientation. On the other hand, the inability to provide moral impartiality in the communitarian approach, whose cultural attachment makes its arguments so culturally embedded, is driven by individualist liberalism. The collective values and consensus trampling on the rights of individual members of these (as well as other) communities is inevitable. In other words, the communitarian position seems to equate a liberal, individualistic promotion of universal values with cultural assimilation that results in the fragmentation and demise of various traditional cultures. 
Even though considered to be fragile States, both China and Indonesia are praised by Kaplan (2012). He states,

The countries most successful at promoting development and reducing poverty have been horizontally social cohesive, not vertically so, because of how important this is when governments do not work well. Places like China, Vietnam, Indonesia, and the rest of East Asia have improved the lives of over a billion poor people over the past two generations not because they have had good governance, progressive taxes, or followed a certain policy playbook, but because they have had the social glue that lubricated business and encouraged leaders to focus on inclusive development. Donors have often been befuddled by fragile States, with some even calling them a wicked problem. These difficulties, however, say more about donors than they do about fragile States.

From 1998 to 2003, based on statistics from China's Information Office of the State Council, approximately 19 million workers laid off by State Owned Enterprises (SOEs), were reemployed, most of them by SMEs (Li, 2012). In 2010, the tax revenue collected from private enterprises in China accounted for almost 11 per cent of the total tax intake ( $\mathrm{Li}, 2012)$. It is possible that the data of private enterprises in China includes larger enterprises, because in comparison, the contribution of tax revenue from micro small and medium enterprises (MSMEs) in Indonesia is still minimal, only three per cent of the total tax revenue (Financial Business.com, 2015). In Indonesia Small Medium Enterprises face a heavy burden of one per cent of tax from business turnover. However, the modification of the regulation is still being processed. SMEs with a turnover range of IDR300 million per month will be charged at a lower rate layer, that is 0.25 per cent, while SMEs with an annual turnover range of between IDR300 million to IDR 4.8 billion will be subject to a higher tariff layer, that is, 0.5 per cent (Adelia, 2016). SMEs account for around 80 per cent of China's manufacturing employment and around 80 per cent of new urban employment; they employ more low income workers and socially vulnerable groups and sometimes are the only source of employment in poorer regions ( $\mathrm{Li}, 2012)$. SMEs are estimated to contribute more than 60 per cent of China's GDP ( $\mathrm{Li}, 2012)$ while in Indonesia they contribute 58 per cent of total GDP.

Cooperatives are civil society actors (Coopeurope.coop, 2012). A cooperative is categorized as social enterprise. This classification is based on a discussion about social entrepreneurship with the British Council in Jakarta in July 2016 at the University of Atmajaya, because cooperative's goal is to produce surplus which is comparable to profits in private enterprise (Skurnik, 2002); however, both strive to be economically efficient. A cooperative is an entrepreneurial business entity. The difference between a cooperative and a limited company is that the production of profit is for its owners while the cooperative is for its members (Skurnik, 2002). The surplus is returned to the members in proportion to their use of the company's services, after keeping the reserves necessary to develop the company. A cooperative is just a different variety of company, and hence only one form of enterprise among many. The average cooperative business size in Indonesia is IDR872.51 million, thus it fits within the category of small businesses, based on the SME law or the Act No.20/2008 classification (bi.go.id, 2017). All 36.4 million cooperative members contribute 30 per cent of the total labour force (Meisari, 2016). In China, cooperatives are the most common form of association that are supported by the ICCIC (International Committee for the Promotion of Chinese Industrial Cooperatives) in the enhancement of women's position, poverty alleviation, etc. which can be found in Gansu, Sichuan, Hebei, Henan, Shanghai, Yunnan, Guizhou, Anhui, and Jilin.

Gung Ho is the slogan of a project initially founded by Rewi Alley in 1938 to foster genuine democratic cooperatives in various parts of China. Unfortunately, the farmers' associations have a weak link in overcoming legal difficulties since the legal status of these associations was only clarified with the new Cooperatives Law in 2006 (Soesilo, 2012).

Silk Road (Unesco, 2000) is, in fact, a relatively recent term introduced by President Joko Jokowi Widodo when he mentioned the Silk Road Fund through the Asian Infrastructure Investment Bank. At that time where he invited Chinese companies and others to help build a maritime highway from the west to the east of Indonesia and 24 seaports and deep seaports, 
to reduce commodity price disparities. This was mentioned during the CEO Summit of the Asia-Pacific Economic Cooperation forum in Beijing on 10 November 2014. Historically, as Jokowi and President Xi Jinping put it, Indonesia provides natural resources and China supports Indonesia's maritime infrastructure (Luhulima, 2016).

If Porter's work underlined the constructive side, the FSI emphasized the opposite. Porter's competitiveness is considered as a bridge between strategic business management theory and international economics. The country competitiveness index has been used worldwide to calculate comparable positive side, while the FSI calculates the negative side. The FSI uses four social indicators, two economic indicators and six political indicators. The social indicators are demographic pressures, refugees and IDPs, group grievances, and human flight. The economic indicators are uneven development, poverty and economic decline. The political indicators are legitimacy of the state, public services, human rights, security apparatus, factionalised elites and external intervention.

\section{METHOD}

This research has three steps because of the existence of three actors, Indonesia, China and the EU, which creates the Triangular Cooperation ( $\operatorname{TrC})$. The first research step is the power of the EU (normative power) by using the Fragility State Index as a yardstick, the second step is the loan analysis using the ten principles of the EU as a benchmark, and the third step is analysing whether the cooperation or competition exists using the principle of the SSC (see Figure 1).

The Triangular Cooperation $(\mathrm{TrC})$ sees the connection among Indonesia, China, and the EU, as 'Southern-driven partnerships between two or more developing countries, supported by a developed country(ies) or multilateral organisation(s), to implement development cooperation programs and projects' (UNDP, 2009).

Between Indonesia and China, the analysis uses the SSC principle which is

a process whereby two or more developing countries pursue their individual andlor shared national capacity development objectives through exchanges of knowledge, skills, resources, and technical know-how, and through regional and interregional collective actions, including partnerships involving Governments, regional organizations, civil society, academia and the private sector, for their individual and/or mutual benefit within and across regions. South-South cooperation is not a substitute for, but rather a complement to, North-South cooperation (UNDP, 2009).

In elaborating the position of Indonesia, China and the EU, the UNDP standpoint can be used as the basis of the analysis in three activities. In elaborating the position of Indonesia,

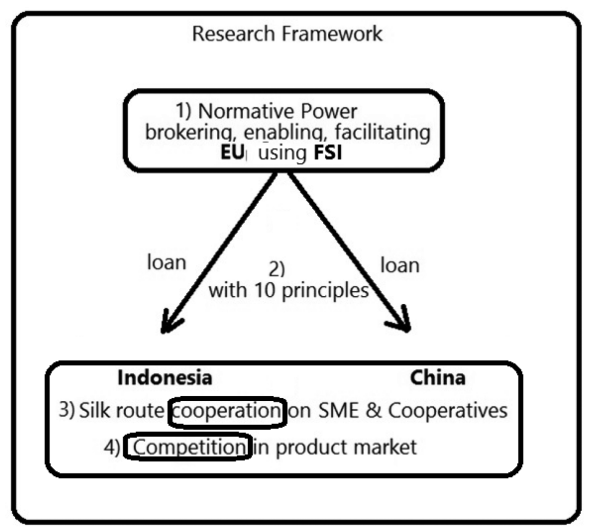

Figure 1. Research framework. 
Table 4. Normative power of EU to be imposed by China and Indonesia.

\begin{tabular}{|c|c|c|c|c|c|c|}
\hline \multirow[b]{3}{*}{ Countries } & \multicolumn{4}{|c|}{ Unit Cost for Manajer per day } & \multirow[b]{3}{*}{ China } & \multirow[b]{3}{*}{ Indonesia } \\
\hline & \multicolumn{4}{|c|}{ EU group } & & \\
\hline & 1 & 2 & 3 & 4 & & \\
\hline EURO & 294 & 280 & 164 & 88 & 77 & 47 \\
\hline Ratio to Indonesia & 6.26 & 5.96 & 3.49 & 1.87 & 1.64 & 1.00 \\
\hline
\end{tabular}

EU 1: Austria, Denmark, Ireland, Luxembourg, Netherlands, Sweden.

EU 2: Belgium, Finland, France, Germany, Italy, UK.

EU 3: Cyprus, Czechia, Greece, Malta, Portugal, Slovenia, Spain.

EU 4: Bulgaria, Estonia, Croatia, Latvia, Lithuania, Hungary, Poland, Romania, Slovakia.

Source: Guidelines for the use of the grant, Erasmus+Programme, 2017.

China, and the EU, the UNDP standpoint (UNDP, 2009) has a strong role to play as a knowledge broker, capacity development supporter, and partnership facilitator using EU guidelines as normative power, as seen in Table 4.

The UNDP will focus on: (1) brokering knowledge on scalable development solutions and analyse what has worked and what has not, with systematic information of who, where, and what is happening in South-South and Triangular Cooperation; (2) enabling harmonisation of policies, legal frameworks, and regulations to increase opportunities and maximise mutual benefits of South-South exchanges, while supporting capacity development of Southern partners to better implement SSC and TrC initiatives; and (3) facilitating partnerships, fostering innovations, and promoting the scaling-up of promising ideas. In its South-South and Triangular Cooperation efforts, the UNDP connects and works together with a wide variety of interested stakeholders from governments to private sectors and civil societies.

From the donor side, this analysis uses the EU benchmark (Morcos \& Roder, 2007) in giving aid to fragile States that should be as follows: (1) Context is the starting point; (2) Do no harm; (3) State building is the central objective; (4) Prioritise prevention; (5) Political, security and development objectives are linked; (6) Promote non-discrimination as a basis for inclusive and stable societies; (7) Align with local priorities in different ways and in different contexts; (8) Agree on practical coordination mechanisms between international actors; (9) Act fast... but stay engaged long enough to give success a chance; (10) Avoid pockets of exclusion (aid orphans).

\section{RESULTS}

From the point of view of SSCs regarding the ten principles of aid, only four elements can be used for cooperation between Indonesia and China. The four elements are the first, sixth, seventh, eighth principles, and these are elaborated on as follows:

First Principle-Context is the starting point: It linked Indonesia and China in entrepreneurship both in positive and negative side. In 2002, the Central Government of China declared the SME Promotion Law, showing a major change in attitude from the central government towards SMEs after years of market reform, even though they were not permitted to exist until 1988, ten years after economic reform started in 1978 (Li, 2012). In Indonesia the SME Law Number 20, 2008, was launched with the aim to foster and expand its business in order to build a national economy based on equitable economic democracy. Since reaching it highest annual economic growth of 13.6 per cent in 2007 , China has been showing a slowdown. China's growing middle class meant it could not constantly be a low-wage and low-cost producer, but would be able to shift to a US-type consumption model within a decade (Whittaker 2016). Some migration of apparel manufacturing from China to Indonesia is an inevitable consequence, and even encouraged by the Chinese government because China 
must embrace research and high technology production to transform its economy as South Korea and Japan once did more efficiently at mass manufacturing. However, vigorous economic growth demands that China increases its service sector and prioritize higher-skilled manufacturing jobs with greater compensation (Chu 2013). While China's economy has been diminishing, Indonesia has been increasing after viewing the potential in its huge consumer market. For example, the teak furniture maker Broxo Indonesia, which has been exhibiting at the China-ASEAN Expo since 2013, had an annual sales growth to China of 30 per cent until 2015 (Tan, 2015).

As the second, third, fourth, and fifth principles are not relevant, the elaboration goes to the Sixth Principle-Promote non-discrimination as a basis for inclusive and stable societies. Promoting MSEs, the majority of which are privately owned, is a government priority in the drive to build a well-off and harmonious society. While MSMEs as a whole remain credit constrained, it is the MSEs that have over time become the forgotten segment. To overcome this, the Chinese government created The Programme for the Development of Chinese Women, a new legal and organisational framework for the period 2011-2020. Cooperatives are the most common form of association supported by the ICCIC. Unfortunately, the farmers' associations in China have weak links in overcoming legal difficulties since the legal status of these associations was only clarified with the new Cooperatives Law in 2006. The inclusive growth has to face the annual growth of group grievance in Indonesia which is 1.90 per cent with China at 1.1 per cent. In this case China is better in comparison to Indonesia because it has become the first developing country to realise the UN's MDGs. China also follows the Beijing Platform for Action, the Outcome Document, Convention on the Elimination of All Forms of Discrimination against Women and the MDGs. Three decades of China economic growth have focused more on infrastructure building than on a functioning society. However, within the MSME sector, micro and small enterprises (MSEs) will play an indispensable role in meeting these challenges. Though, in the case of Hubei in China, entrepreneurship movement went too far, as there was also a shift to commercial farming under Dragonhead Enterprises that increased economic gains to participating countries but which also raised concerns about targeting the poor. While China is able to meet its MDGs, Indonesia is not, because its target is off track, although many agendas of development, security, diplomacy, trade, migration and beyond are actively deployed by international actors. In Indonesia, cooperative discrimination policies exist, such as Article 21 from Law 44, 2009 about hospitals (hukumonline.com, 2009). Private hospital management in Indonesia excludes cooperatives as a formal legal entity, while in other countries, health cooperatives are very common in managing hospitals (IHCO Coop 2016). No wonder that cooperatives as an inclusive growth actor contribute only 1.9 per cent of total GDP, lagging behind SOEs and private companies. While the annual growth of Competition Index in Indonesia has been decreasing at a rate of -1.2 per cent, at the same time the rate of Indonesia Gini coefficient rose 2 per cent from 2007 to 2016 as seen in Table 5. No wonder that Robison doubted the political and economic intentions and capacities of Indonesia to envisage the power of the state (Kompas.com, 2016 and Robison, 2016).

Seventh Principle-Align with local priorities in different ways and in different contexts: This principle is relevant to be discussed, but with several notes. A lot of resentment has been ignited, spurred by social media that might ignite conflicts, because the Silk Road Programme contradicts the local priorities to give employment to Indonesian people. The revocation of Article 26, Paragraph 1, the Manpower and Transportation Minister Regulation No 12/2013 deletes the regulation that requires that foreign workers must be able to speak local Indonesian. It is against Article 3 Paragraph 1 of the Manpower Minister Regulation No 16/2015 (Riyadi 2016). On the other hand in China since the mid-1990s, in order to align with local priorities, UN IFAD's strategic partners are the Government of China, and the provincial Association of Woman Federation and Rural Credit Cooperatives (RCC) network.

Eighth Principle-Agree on practical coordination mechanisms between international actors: Practical coordination is needed on several topics. However, the most urgent issue is drug trafficking between China and Indonesia. For this cooperation, the Indonesia Global Maritime Fulcrum (GMF) is more inward looking to Indonesia; it focuses on the internal waters 
Table 5. Indonesia annual growth of regulation index and Gini coefficient compared to China.

\begin{tabular}{|c|c|c|c|c|c|c|c|}
\hline \multirow[b]{2}{*}{ Year } & \multicolumn{5}{|c|}{ Indonesia competitiveness index } & \multirow{2}{*}{$\begin{array}{l}\text { Gini } \\
\text { IDN }\end{array}$} & \multirow{2}{*}{$\begin{array}{l}\text { Coef } \\
\text { China }\end{array}$} \\
\hline & Agriculture & Manufacture & Services & Trade & Total & & \\
\hline 2007 & 0.7 & 0.65 & 0.75 & 0.85 & 0.74 & 0.35 & \\
\hline 2008 & 0.7 & 0.6 & 0.75 & 0.85 & 0.73 & 0.428 & 0.428 \\
\hline 2009 & 0.7 & 0.6 & 0.8 & 0.85 & 0.74 & 0.37 & \\
\hline 2010 & 0.7 & 0.55 & 0.8 & 0.85 & 0.73 & 0.38 & \\
\hline 2011 & 0.7 & 0.55 & 0.85 & 0.85 & 0.74 & 0.41 & \\
\hline 2012 & 0.65 & 0.55 & 0.8 & 0.8 & 0.7 & 0.41 & 0.422 \\
\hline 2013 & 0.6 & 0.6 & 0.8 & 0.8 & 0.7 & 0.41 & \\
\hline 2014 & 0.6 & 0.6 & 0.75 & 0.8 & 0.69 & 0.41 & \\
\hline 2015 & 0.65 & 0.7 & 0.75 & 0.8 & 0.73 & 0.4 & \\
\hline 2016 & 0.61 & 0.56 & 0.77 & 0.75 & 0.67 & 0.39 & \\
\hline $\begin{array}{l}\text { Annual } \\
\text { growth }\end{array}$ & $-1.48 \%$ & $-1.56 \%$ & $-0.18 \%$ & $-1.54 \%$ & $-1.21 \%$ & $2.04 \%$ & \\
\hline
\end{tabular}

Source: Indonesia Competitive Index is calculated from Business Competition Supervisory Committee data, 2016. The news also appears in Kontan, 2016. Gini coefficient is calculated from www.bps.go.id as well as data in Indonesia-investment.com (2016) in www.indonesia-investments.com/id/news/todaysheadlines/gini-ratio-indonesia-declines-inequality-narrows/item7113; In China, the data above is from World Bank, while other sources can be found in: https://www.theguardian.com/world/2014/jul/28/chinamore-unequal-richer; the Gini coefficient in China in 2012 was 0.78.

of Indonesia. From a micro enterprise and cooperative point of view, this is seen as beneficial due to the banning of fishing nets used by big companies to harvest all sizes and varieties of fish to protect the environment. However, it is actually ruining the fishing industry in Indonesia due to the short supply of tuna fish from the internal seas. In a maritime country like Indonesia, it is an irony that it has to import tuna from overseas in order to supply the domestic industry (Bisnispos 2016).

\section{CONCLUSION}

The increased maritime cooperation under the revival of the Silk Road has made some progress in economic development in Indonesia; however, at the initial process, it is dominated by competition rather than cooperation. Indonesian SMEs and cooperatives have been worried by the influx of Chinese products because of their low prices. Later on, China started showing an economic slowdown and some migration of low-tech industry to Indonesia happened. For example the apparel manufacturing has been moving to Indonesia because China must embrace research and high technology production to transform its economy to be more efficient at mass manufacturing. For Indonesia and China, growth and comfort never coexist as noted by Ginni Romety (Business Insider, 2015). However, the process is already happening if analyzed using the international relations framework in the form of both competition as well as cooperation (the SSC).

When dealing with Triangular Cooperation (TrC), even though considered to be fragile States by the EU, both China and Indonesia possess their own footpath of progress. Both countries are praised by Kaplan not because he is impressed by good governance, progressive taxes, or followed a certain policy playbook, but because they have the social glue that lubricates business and encourages leaders to focus on inclusive development. Kaplan states that donors have often been confused by fragile States, with some even calling them a 'wicked problem'. These difficulties, however, say more about donors than they do about fragile States. Compare to Indonesia and China, fragility problems within the EU member states are already increasing (one big example of which is Brexit), even though some part of the FSI calculation for EU's fragility are decreasing (as seen in Table 3). Therefore, it would be 
wiser, especially for China, to put the FSI implications aside and insist on their own path of development (Xie, 2016).

If using the following three basis analysis, EU mostly possesses comparative advantage in; (1) brokering knowledge, (2) enabling harmonisation of policies and, (3) facilitating partnerships. In giving assistance to Indonesia and China, as the supply side of aid in Triangular Cooperation, it is beneficial for EU if fragility consideration is used for evaluating the recipient countries. However, based on the demand side of aid, both Indonesia and China have their own dynamics of cooperation and competition which is completely different. They are fundamentally distinctive. Many would group these types of initiative together as 'aid' as opposed to a 'trade' type activity. China, due to its impressive progress, is often considered as a doer country. It is completely the opposite compared to EU, that typically characterised as a distinctive post-Westphalian organisation with ten principles of assistance. When using all ten principles of fragile state assistance from the EU in the case of SMEs and cooperatives, only the first, sixth, seventh, eighth, ninth and tenth principles can be used.

When analysing the competing power dynamics between China and Indonesia as sovereign states in the hope of alliance building with the revival of the Silk Road since President Jokowi's administration, some precaution have to be taken into account. It is important to mitigate threat perceptions, especially from the Indonesia side. In modern international system, whose lawlessness is only partially offset by the evolution of issue-based institutions and regulatory regimes, some elements of cooperation only relevant if the win-win solution is achieved. This is unlike the EU whose members have voluntarily agreed to pool sovereignty and accept the appearance of supranational authority over key areas of domestic and international policymaking.

From the EU ten principles of giving aid, there are five principles that are not relevant in the South-South Cooperation of Indonesia and China, especially the second principle (do no harm), the third principle (state building is the central objective), the fourth principle (prioritise prevention), the fifth principle (political security), the ninth principle (act fast), and finally the tenth principle (aid orphans). This is elaborated on as follows:

The second 'Do no harm' principle cannot create cooperation because first, it is more about competition, such as the influx of Chinese products in Indonesia that has caused bankruptcy for some Indonesians SME, and second, due to lawlessness. Chinese ships seized by the Indonesians six years ago were scuttled and detonated and then in retaliation, an Indonesian ship was threatened at gunpoint by Chinese vessels off the Natuna islands for having arrested Chinese trawlers. The third principle, 'State building as the central objective' is not relevant for SMEs and cooperatives due to their frantic schedule in earning their own living, which does not allow time to think about big issues like state building. The fourth principle 'Prioritise prevention' is more about government policy rather than SME and cooperative daily activities; while the fifth principle, 'Political, security and development objectives are linked' is also not relevant for SMEs and cooperatives. In the ninth principle, 'Act fast... but stay engaged long enough to give success a chance', Indonesian and Chinese cooperation has happened very fast; especially in infrastructure for example the development of fast trains connecting Jakarta and Bandung (Afrianto, 2016). This has created potential conflict due to a lack of proper planning documents and bias towards big companies, leaving no ample benefits for SMEs and cooperatives. In the bilateral comprehensive strategic partnership between two countries, Xi called for strengthened high-level coordination, connecting China's twentyfirst century Maritime Silk Road initiative with Indonesia's Global Maritime Axis vision, in which Indonesia also supports and is willing to strengthen cooperation with China in trade, investment, finance, infrastructure and other areas (China.org 2016). Finally the tenth principle, 'Avoid pockets of exclusion (aid orphans)' means that each project should not be in the form of enclave, but should have good impact for the environment and community such as mentioned by the spirit of SSC. For example, when Chinese workers came to Indonesia along with the Bilateral Agreements of Foreign Debt between Indonesia and China the sociological impact should be calculated, because job seekers in Indonesia are also still abundant. In general, this agreement requires that infrastructure development undertaken by Chinese companies consists of one package using Chinese workers brought from China. With increasing 
demographic pressure in China, the perceived Chinese influx to Indonesia is inevitable from the point of view of China. But, based on reciprocity principle of the Silk Road programme, some resentment have to be reduced. As planned, by employing Chinese workers in Indonesia. China is also able to invite the same number of Indonesians to China. Chinese investment in Indonesia accounts for six per cent of the combined investment realisation of \$7.29 billion in the first quarter, placing China in fourth position after Singapore, Japan and Hong Kong. The pocket of exclusion of Chinese investment is perceived as dangerous from an Indonesian point of view, and it is not in line with the spirit of SSC.

The challenges faced by fragile States are multidimensional. Third World communitarians claim that a form of cultural imperialism that smuggles the undesirable Western egoist lifestyle (like the EU) into non-Western traditional communalist cultures is an attempt by Western liberal individualists to universalise their value orientation. The political, security, economic and social spheres are interdependent factors, such as the OECD principles in the ambitious goal of assisting in the building of effective, legitimate and resilient states. However, it seems too normative for the SME and cooperative case, since State effectiveness is a complex and multidimensional phenomenon. However, SMEs and cooperatives cannot be effective if there is no power. Despite the upper-hand position of the EU as the lender, or principal donor entity in the lending scheme, the EU has been labelled as possessing only normative power, especially when dealing with China as the new world superpower. There are six utmost critical functions of capacities to perform effectiveness, these are to: (1) monopolise the legitimate use of violence (coercive capacity), (2) extract resources (extractive capacity), (3) shape national identity (assimilative capacity), (4) regulate the society and economy (regulatory capacity), (5) maintain internal coherence of state institutions (amalgamating capacity), and (6) distribute resources (redistributive capacity) (Wang, 2014; Pye, 1966; Binder et al., 1971; Grew, 1978 in Metreveli, 2016). The EU is an ideational, value driven power in the $\operatorname{TrC}$ framework. It is dominated by supply driven assistance's motive on the international arena rather than partnership and demand side. It is not based on the analysis of international identity in traditional nationstate discourse (Manners, 2002; Youngs, 2004 in Metreveli 2016). In this case, it is good to become a reminder that both the TrC and SSC are aimed mostly to implement development cooperation rather than competition, and there is no exception for the case of relationship between Indonesia, China and the EU. In a nutshell, not all ten principles of EU's point of view as the donor country are relevant to cope with Fragile States aid, especially when assisting the SMEs and cooperatives in both Indonesia and China.

\section{REFERENCES}

Adelia, Melly Kartika. (2016). Tarif Pajak UMKM akan Diturunkan 0.25-0.50 Persen. Bengkel UKM. http://www.bengkelumkm.com/id-288-post-tarif-pajak-untuk-umkm-turun-menjadi-02505-persen. html

Afrianto, Dedy. (2016). Top Speed $350 \mathrm{Km} / \mathrm{Jam}$, Begini Penampakan Kereta Cepat Jakarta-Bandung. Okezone Finance. http://economy.okezone.com/read/2016/09/14/320/1489133/top-speed-350-kmjam-begini-penampakan-kereta-cepat-jakarta-bandung. Retrieved on September, 102016.

Austin, James. (2000). The collaboration challenge: How nonprofits and businesses succeed through strategic alliances. Strategic Marketing for Nonprofit Organizations, page 224.

Bi.go.id. (2017). Data Kredit UMKM Desember 2016, http://www.bi.go.id/id/umkm/kredit/data

Binder, Leonard, James S. Coleman, Joseph LaPalombara, Lucian W. Pye, Sidney Verba, \& Myron Weiner. (1971). Crisis and sequences in political development. Princeton: Princeton University Press.

Chu, Kathy. (2013). China manufacturers survive by moving to Asian neighbors. http://www.wsj.com/articles/SB10001424127887323798104578453073103566416, retreived on August, 262016.

Davies, Howard, \& Ellis Paul. (2000). Porter's competitive advantage of nations: Time for the final judgement? Journal of Management Studies, 37(8), 1189-1213. doi:10.1111/1467-6486.00221

Erasmus+Programme. (2017). Guidelines for the use of the grant, capacity building in the field of higher education, for grants awarded in 2016 under Call EAC/A04/2015

Farnell, John \& Paul Irwin Crookes. (2016). The politics of EU-China economic relations: An uneasy partnership. United Kingdom: Palgrave Macmillan. 
Financial Business.com. (2015). Kontribusi Penerimaan Pajak dari UMKM Hanya 3\%. http://finansial. bisnis.com/read/20150903/10/468689/kontribusi-penerimaan-pajak-dari-umkm-hanya-3. Retreived on September 12016.

Meisari, Dewi. (2016). Koperasi: Solusi Pembangunan dengan Pemerataan? Seminar Koperasi dan Pembangunan Berkelanjutan, MM FEB UI, 27 July 2016, Kampus UI Salemba.

Hellsten, Sirkku K. (2010). Empowering the invisible: Women, local culture and global human rights protection. Thought and Practice: A Journal of the Philosophical Association of Kenya (PAK) New Series, 2(1), 37-57.

IFAD. (2013). Consolidated financial statements of IFAD as at 31 December 2012. https://webapps.ifad. org/members/eb/108/docs/EB-2013-108-R-13-Rev-1.pdf. Retreived on September 12013.

Kaplan, Seth, (2012). Horizontal versus vertical social cohesion: Why the differences matter. Fragilestates. http://www.fragilestates.org/2012/03/12/horizontal-versus-vertical-social-cohesion-why-the-differencesmatter/. Retreived on August, 262016.

Kompas.com. (2016). Profesor Australia: Indonesia Tak Punya Kapasitas untuk Jadi Kekuatan Baru di Dunia http://internasional.kompas.com/read/2016/07/08/13300091/profesor.australia.indonesia.tak. punya.kapasitas.untuk.jadi.kekuatan.baru.di.dunia

Li, Wei. (2012). Small and medium enterprises - the source of China's economic miracle - and their financing challenges. CSC Academic Group: Enterprise Development. http://sydney.edu.au/china studies_centre/china_express/issue_3/features/small-and-medium-enterprises.shtml. Retreived on August, 262016.

Luhulima, C.P.F. (2016). Superimposing China's 'maritime Silk Road' on Indonesia. The Jakarta Post. http://www.thejakartapost.com/news/2016/06/10/superimposing-china-s-maritime-silk-road-indonesia.html

Manners, Ian. (2000). Normative power Europe: A contradiction in terms? http://rudar.ruc.dk:8080/ bitstream/1800/8930/1/Ian_Manners_Normative_Power_Europe_A_Contradiction_in_Terms_ COPRI_38_2000.pdf.on September 102016.

Metreveli, Tornike. (2016). The EU's normative power-its greatest strength or its greatest weakness? http://www.atlantic-community.org/app/webroot/files/articlepdf/EUNormativePower.pdf. Retreived on September 12016.

Morcos, K. \& Roder, Anne Friederike. (2007). The OECD's work on fragile states and situations. Transforming Fragile States-Examples of Practical Experience. Nomos Verlagsgesellschaft mbH \& Co. KG.

Pye, Lucian W. (1966). Aspects of political development. Boston: Little, Brown and Company.

Ramalingam, Ben. (2012). State fragility as a wicked problem? http://aidontheedge.info/2012/02/15/ state-fragility-as-a-wicked-problem/. Retreived on October 10, 2012.

Riyadi, Muhammad A. (2016). Illegal Chinese workers invade Indonesia. Gres.news. http://gres.news/ news/politics/108616-illegal-chinese-workers-invade-indonesia/0/. Retreived on August, 262016.

Robison, Richard. (2016). Why Indonesia will not be Asia's next giant. The University of Melbourne, 14 July, $2016 \mathrm{http} / / /$ indonesiaatmelbourne.unimelb.edu.au/why-indonesia-will-not-be-asias-next-giant/. Retreived on August, 262016.

Silk Road Foundation. (2007). Richthofen's silk roads: Toward the archaeology of a concept. The Bridge between Eastern and Western Cultures, 5(1).

Skurnik, Samuli. (2002). The role of cooperative entrepreneurship and firms in organizing economic activities— past, present and future. http://lta.hse.fi/2002/1/lta_2002_01_d6.pdf. Retreived on December $1,2012$.

Soesilo, Nining I. (2014). Corporate level evaluation on fragile states and conflict situations. Case Study in Indonesia and the Philippines. UN IFAD.

Tan, Valarie. (2015). Indonesia struggles to stay competitive in Chinese market. Channel NewsAsia. http://www.channelnewsasia.com/news/business/indonesia-struggles-to/2144352.html. Retreived on September 2016.

The Diplomat.com. (2015). Indonesia, China seal 'maritime partnership,' http://thediplomat.com/2015/03/ indonesia-china-seal-maritime-partnership/. on October 222016.

UNESCO. (2000). About the Silk Road. http://en.unesco.org/silkroad/about-silk-road. Retreived on August, 262016.

UNDP. (2009). Frequently asked question, the south-south and triangular cooperation. http://www.undp. org/content/dam/undp/library/Poverty $\% 20$ Reduction/Development $\% 20$ Cooperation $\% 20$ and $\% 20$ Finance/SSC_FAQ\%20v1.pdf. Retreived on February 22016.

Wang, Shaoguang. (2014). Democracy and state effectiveness. www.cuhk.edu.hk/gpa/wang_files/ DemocracyandState.doc. Retreived on September 192016.

Wheeler, Brian Wheeler \& Alex Hunt. (2016). Brexit: All you need to know about the UK leaving the EU. http://www.bbc.com/news/uk-politics-32810887. Retreived on September 202016. 
Whittaker, Matt. (2016). How to invest in China's changing economy. http://money.usnews.com/investing/articles/2016-04-01/how-to-invest-in-chinas-changing-economy. Retreived on September 52016. Xie, Chao. (2016). Fragile States Index 2016, China and the FSI: Decennary Trends, 2007-2016. IPCS. http://www.ipcs.org/article/india/china-and-the-fsi-decennary-trends-2007-2016-5123.html. Retreived on October 212016.

Youngs, R. (2004). Normative dynamics and strategic interests in the EU's external identity. Journal of Common Market Studies 42(2), 415-35. http://media.library.ku.edu.tr/reserve/resfall08_09/ INTL533_BRumelili/22ndDecember/Normative_dynamics_wiley.pdf. Retrieved on October 222016. 